\title{
PENERAPAN MODEL DISCOVERY LEARNING PADA MATERI SISTEM KOORDINASI UNTUK MENINGKATKAN HASIL BELAJAR PESERTA DIDIK
}

\author{
Zelin Agusriyalni ${ }^{1 *}$, Irdam Idrus ${ }^{1}$, Yennita ${ }^{1}$ \\ ${ }^{1}$ Program Studi Pendidikan Biologi, Fakultas Keguruan dan Ilmu Pendidikan Universitas Bengkulu \\ Email: zelinagusriyalni24@gmail.com
}

\begin{abstract}
Abstrak
Penelitian ini bertujuan untuk mendeskripsikan hasil belajar peserta didik dengan model Discovery Learning pada materi Sistem Koordinasi. Jenis penelitian ini adalah penelitian tindakan kelas. Penelitian tindakan kelas ini terdiri dari dua siklus, masing-masing siklus terdiri dari 4 tahap yaitu: tahap perencanaan, pelaksanaan, pengamatan dan refleksi. Subjek penelitian ini adalah seluruh peserta didik kelas XI IPA 2 SMAN 1 Kepahiang. Variabel penelitian ini adalah model Discovery Learning dan hasil belajar. Teknik pengumpulan data dalam penelitian ini yaitu observasi dan tes. Persentase ketuntasan hasil belajar peserta didik ranah pengetahuan pada siklus I yaitu $54,28 \%$ yang termasuk kedalam kategori belum tuntas dan pada siklus II persentase ketuntasan hasil belajar peserta didik ranah pengetahuan mengalami peningkatan menjadi $82,85 \%$ dan termasuk dalam kategori tuntas. Selanjutnya, hasil belajar peserta didik dalam ranah keterampilan pada siklus I diperoleh skor rata-rata yaitu 11,94 termasuk kategori cukup dan mengalami peningkatan pada siklus II menjadi 13,28 termasuk kategori baik. Dari hasil penelitian dapat disimpulkan bahwa model Discovery Learning dapat meningkatkan hasil belajar peserta didik di kelas XIIPA ${ }_{2}$ SMAN 1 Kepahiang.
\end{abstract}

Kata kunci : Hasil Belajar, Model Discovery Learning

\begin{abstract}
The aim of this research was to describe the learning outcomes of students with Discovery Learning model on coordination system topic. The type of this research was Classroom Action Research (CAR). This Classroom action research consists of two cycles, each cycle consisting of four stages, namely: planning, implementation, observation and reflection. The subject were all students of class XI IPA SMAN 1 Kepahiang. The variables of this research were Discovery Learning model and learning outcomes. Technique of collecting data in this research was observation and test. The percentage completeness of learning outcomes of students in knowledge realm of first cycle was $54,28 \%$ included in the category of not yet complete and in second cycle the percentage completeness of learning outcomes of students in knowledge realm has increased to $82,85 \%$ and included in the complete category. Furthermore, the learning outcomes of students in psychomotor realm of the first cycle obtained an average score of 11.94 including the sufficient category and experienced an increase in the second cycle to 13.28 including the good category. The results of this research can be concluded that the model Discovery Learning could improve the activities and learning outcomes of students at XI IPA 2 SMAN 1 Kepahiang.
\end{abstract}

Keywords: Learning Outcomes, Discovery Learning Model

\section{PENDAHULUAN}

Sistem pendidikan yang ada di negara

Indonesia telah mengalami banyak

perubahan seiring berkembang zaman.

Perubahan sistem pendidikan tersebut

dimulai dari pendidikan tingkat dasar atau rendah hingga ke tingkat yang lebih tinggi (Utomo, 2015).

Undang-Undang nomor 20 Tahun 2003

yang memuat tentang Sistem Pendidikan 
Nasional menegaskan bahwa pendidikan adalah suatu usaha yang telah direncanakan untuk mewujudkan suasana proses belajar dan pembelajaran yang kondusif untuk peserta didik supaya bisa aktif dalam mengembangkan potensi dirinya. Sehingga peserta didik dapat memiliki kekuatan spiritual keagamaan, pengendalian diri, kepribadian, kecerdasan, akhlak mulia, serta keterampilan yang diperlukan dirinya, masyarakat, bangsa dan negara (Kemendikbud, 2014).

Biologi merupakan bagian dari sains yang mengandung empat hal, yaitu produk, proses, sikap dan teknologi. Produk pada biologi mencakup konsep-konsep yang kompleks dan banyak sehingga diperlukan penguasaan konsep yang komprehensif untuk dapat memahaminya. Penguasaan konsep peserta didik dapat ditentukan oleh cara dan proses belajar peserta didik, serta dapat diukur dari hasil belajar khususnya hasil belajar kognitif. Apabila pembelajaran semakin bermakna maka penguasaan konsep atau hasil belajarnya semakin baik (Ashyuri, 2017).

Berdasarkan observasi awal dan wawancara yang telah dilakukan dengan guru Biologi kelas XI IPA 2 SMAN 1 Kepahiang tahun ajaran 2018/2019, diperoleh beberapa informasi sebagai berikut: 1) Minat belajar peserta didik masih kurang, karena masih sedikitnyanya variasi model pembelajaran yang dilakukan guru; 2) Peserta didik kurang berpartisipasi didalam proses pembelajaran seperti bertanya dan mengemukakan pendapatnya dalam mengidentifikasi masalah yang relevan dengan bahan pelajarannya. Sehingga hasil belajar Biologi peserta didik masih ada yang rendah atau belum mencapai KKM (Kriteria Ketuntasan Minimal) $\geq 75$ yang telah ditetapkan SMAN 1 Kepahiang.
Discovery Learning merupakan suatu model pembelajaran yang dapat digunakan untuk memecahkan permasalahan dalam proses belajar dan pembelajaran secara intensif dibawah pengawasan guru. Pada model discovery, guru membimbing peserta didik untuk menjawab atau memecahkan suatu masalah. Discovery Learning juga dapat dikatakan sebagai metode pembelajaran kognitif yang menuntut guru supaya lebih kreatif dalam menciptakan situasi belajar yang dapat membuat peserta didik belajar menjadi aktif menemukan pengetahuan sendiri (Mulyatiningsih, 2013). Melalui model Discovery Learning ini peserta didik bisa menjadi lebih dekat dengan apa yang menjadi sumber belajarnya, rasa percaya diri peserta didik juga akan meningkat karena dia merasa apa yang telah dipahaminya ditemukan oleh dirinya sendiri, kerjasama dengan temannya pun akan meningkat, serta tentunya menambah pengalaman peserta didik (Putrayasa, dkk, 2014).

Dalam mendukung penerapan model Discovery Learning ini nantinya digunakan bahan ajar berupa LKPD dan LDPD dalam proses pembelajarannya. Peserta didik akan melakukan sebuah percobaan atau praktikum sederhana dengan saling bekerjasama satu sama lain dan juga menjawab beberapa pertanyaan yang berhubungan dengan materi yang diajarkan. Dimana nantinya dari praktikum dan pertanyaan tersebut peserta didik akan mudah dalam memahami konsep materi yang diberikan. Keterampilan peserta didik juga akan semakin meningkat selama proses belajar. Sehingga hasil belajar peserta didik tidak hanya ranah pengetahuan saja yang mengalami peningkatan tetapi keterampilannya juga. Jadi, dengan penerapan model Discovery Learning guru 
dapat mengubah pembelajaran yang awalnya teacher centered menjadi student centered.

Adapun penelitian terdahulu yang relevan dengan model Discovery Learning ini yakni penelitian yang telah dilakukan oleh Amyani (2018) yang menyatakan bahwa menggunakan model pembelajaran Discovery Learning dapat meningkatkan hasil belajar peserta didik kelas $\mathrm{VIII}_{2}$ SMPN 03 Kota bengkulu hingga mencapai kriteria ketuntasan secara klasikal dari 72,5\% hingga $87,5 \%$. Selain itu, menurut Novita (2018) model Discovery Learning dapat meningkatkan hasil belajar peserta didik Kelas VIII ${ }_{5}$ SMPN 4 Kota Bengkulu dengan hasil belajar pada siklus I yaitu $65,71 \%$ meningkat menjadi $82,85 \%$ pada siklus II.

Berdasarkan permasalahan tersebut, maka peneliti berkolaborasi dengan guru biologi untuk menggunakan model pembelajaran Discovery Learning dalam melakukan perbaikan pembelajaran biologi peserta didik di Kelas XI IPA 2 SMA Negeri 1 Kepahiang untuk meningkatkan hasil belajar peserta didik.

\section{METODE}

Jenis penelitian yang digunakan dalam penelitian ini adalah penelitian tindakan kelas yang didasarkan pada model Kemmis dan MC Taggart dengan metode deskriptif. Penelitian ini dilakukan dalam 2 siklus yang terdiri atas empat tahapan yaitu perencanaan, pelaksanaan, observasi dan refleksi. Subjek penelitian ini adalah seluruh peserta didik kelas XI IPA 2 SMAN 1 Kepahiang 2018/2019 yang berjumlah 35 orang peserta didik yang terdiri dari 10 orang laki-laki dan 25 orang perempuan.

Teknik pengumpulan data yang digunakan dalam penelitian ini adalah observasi dan tes. Sedangkan instrumen penelitian yang digunakan adalah lembar observasi dan lembar tes. Lembar observasi digunakan untuk menilai hasil belajar peserta didik dalam ranah keterampilan selama proses pembelajaran di kelas yang terdiri dari 5 indikator pengamatan. Lembar tes digunakan untuk menilai hasil belajar peserta didik dalam ranah pengetahuan yang disajikan dalam bentuk soal objektif (pilihan ganda) yang terdiri dari 10 butir soal yang diberikan kepada peserta didik setelah kegiatan inti pembelajaran.

Teknik analisis data hasil belajar peserta didik dalam ranah pengetahuan dan ranah keterampilan dianalisis dengan cara menghitung nilai rata-rata serta persentase ketuntasan klasikal hasil belajar peserta didik. Data observasi hasil belajar peserta didik dalam ranah keterampilan dapat dihitung rata-rata hasil pengamatan dengan menggunakan rumus:

$$
\mathrm{X}=\frac{\sum X}{N}
$$

(Sudijono, 2014).

Keterangan:

$X \quad$ : Rata-rata skor

$\sum X$ : Jumlah skor pengamatan $\mathrm{DL}$

$\mathrm{N}$ : Jumlah pengamat

Kategori penilaian pada lembar observasi penilaian keterampilan peserta didik dapat dilihat pada Tabel 1.

Tabel 1. Kategori Penilaian Keterampilan Peserta Didik

\begin{tabular}{|c|c|}
\hline Rentang skor & Kategori Penilaian \\
\hline $5-7$ & Kurang \\
\hline $8-10$ & Cukup \\
\hline $11-15$ & Baik \\
\hline Untuk & belajar \\
\hline
\end{tabular}
pengetahuan, perhitungan data persentase ketuntasan hasil belajar peserta didik secara 
klasikal dianalisis dengan menggunakan rumus:

$$
\mathrm{P}=\frac{\sum X}{N} \mathrm{X} 100 \%
$$

(Sudijono, 2014).

Keterangan:

$\sum x$ : Jumlah peserta didik yang mendapat nilai $\geq 75$

$\mathrm{N}$ : Jumlah seluruh peserta didik

P : Persentase ketuntasan hasil belajar peserta didik

Menurut ketentuan yang ditetapkan SMA Negeri 1 Kepahiang, peserta didik yang dikatakan tuntas belajarnya apabila $80 \%$ peserta didik telah memperoleh nilai $\geq 75$.

\section{HASIL DAN PEMBAHASAN}

Berdasarkan dari hasil penelitan yang telah dilakukan, hasil belajar ranah pengetahuan pada siklus I dan II dalam pembelajaran biologi dengan menggunakan model Discovery Learning dapat dilihat pada Gambar 1.

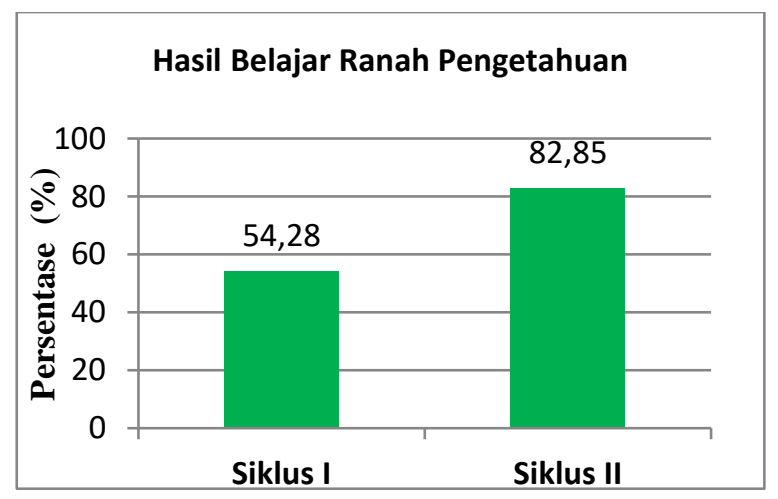

Gambar 1. Persentase Ketuntasan Hasil Belajar Ranah Pengetahuan Peserta Didik Siklus I dan II

Berdasarkan Gambar 1, dapat diketahui bahwa persentase ketuntasan hasil belajar ranah pengetahuan peserta didik secara klasikal pada siklus I yaitu $54,28 \%$ mengalami peningkatan di siklus II menjadi $82,85 \%$.
Hasil belajar peserta didik dalam ranah keterampilan pada siklus I dan siklus II dapat dilihat pada Gambar 2.

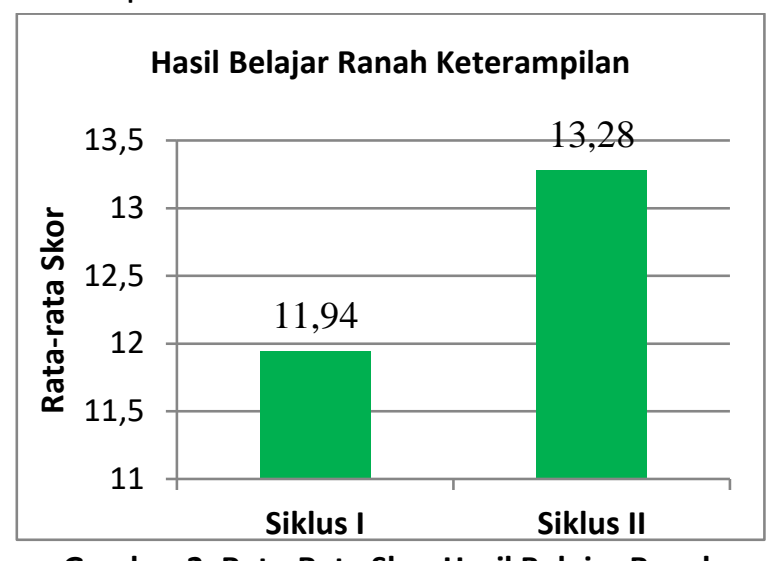

Gambar 2. Rata-Rata Skor Hasil Belajar Ranah Keterampilan Peserta Didik Siklus I dan II

Berdasarkan Gambar 2, dapat diketahui bahwa rata-rata skor hasil belajar ranah keterampilan peserta didik pada siklus I yaitu 11,94 dan mengalami peningkatan di siklus II menjadi 13,28 . Peningkatan jumlah persentase ketuntasan belajar klasikal dan rata-rata skor hasil belajar peserta didik dari siklus I ke siklus II menunjukkan bahwa model pembelajaran Discovery Learning dapat meningkatkan hasil belajar peserta didik. Hal ini sesuai dengan Kemendikbud (2013) dalam Nurgazali (2019) bahwa kelebihan metode Discovery Learning adalah membantu peserta didik untuk memperbaiki dan meningkatkan keterampilanketerampilan serta proses-proses kognitif.

Adanya peningkatan hasil belajar peserta didik dari siklus I dan II dalam ranah pengetahuan maupun ranah keterampilan juga didukung dengan meningkatnya aktivitas mengajar yang dilakukan oleh guru dan aktivitas belajar dari peserta didik dalam tahapan proses pembelajaran di kelas. Hal ini sesuai dengan pendapat Sardiman (2007) yang menyatakan bahwa aktivitas belajar berpengaruh terhadap hasil belajar peserta didik. Tanpa aktivitas, proses belajar tidak 
mungkin terjadi dengan baik. Proses belajar yang baik akan turut mempengaruhi hasil akhir pembelajaran. Adapun penjabaran mengenai setiap tahap atau sintaks pembelajaran pada model Discovery Learning adalah sebagai berikut:

\section{1) Stimulasi}

Pada tahap stimulasi ini, kegiatan mengajar yang dilakukan oleh guru yakni guru memberikan pertanyaan penyelidikan kepada peserta didik. Pertanyaaan penyelidikan yang diberikan guru kepada peserta didik berasal dari fenomena yang terjadi dan sesuai dengan topik pembelajaran yang sedang dipelajari. Pada tahap ini guru memberikan pertanyaan tentang fenomena sistem koordinasi manusia. Tujuan dari adanya pemberian pertanyaan diawal pembelajaran ini untuk merangsang proses berpikir peserta didik agar dapat memecahkan permasalahan yang diberikan oleh guru. Hal ini sesuai dengan pernyataan Widiadnyana (2014), bahwa tahapan pertama yaitu stimulation dengan memberikan pertanyaan-pertanyaan yang relevan dengan kehidupan sehari-hari, yang merangsang peserta didik untuk berpikir serta dapat mendorong eksplorasi. Timbulnya sikap keingintahuan untuk menyelidiki sendiri dan tuntutan eksplorasi, maka akan mengarahkan pemikiran peserta didik untuk memahami terutama tentang permasalahan yang menjadi topik pembelajaran. Hal ini diperkuat dengan pendapat Nasution dalam Suhada (2019) yang mengatakan bahwa permasalahan yang digunakan dalam topik pembelajaran biasanya adalah masalah yang telah ditemukan sebelumnya, bukan yang berdasarkan minat individual.

\section{2) Identifikasi masalah}

Pada tahap identifikasi masalah ini, guru mengarahkan peserta didik untuk mengemukakan pendapatnya tentang pertanyaan yang telah diberikan. Dalam tahap ini, peserta didik dapat mengemukakan sebanyak-banyaknya pendapat ataupun pemikirannya akan permasalahan mengenai sistem koordinasi manusia yang diberikan oleh guru, sehingga peserta didik dapat aktif dalam proses pembelajaran dan menambah pengetahuan awal peserta didik. Kegiatan tersebut sesuai dengan pernyataan Nurgazali (2019) yang menyatakan bahwa pada tahap identifikasi masalah guru memberikan kesempatan kepada peserta didik untuk mencari dan mengumpulkan sebanyak mungkin masalah yang berhubungan dengan tema yang akan dipelajari.

\section{3) Pengumpulan data}

Pada penelitian dua siklus ini terdapat perbedaan yaitu pada siklus I menggunakan LDPD (Lembar Diskusi Peserta Didik). Hal ini dikarenakan pada siklus I materi pembelajaran tentang sistem saraf yang diajarkan kepada peserta didik lebih banyak mengarah ke diskusi dan tidak terdapat materi yang dapat dipraktikumkan. Sedangkan pada siklus II menggunakan LKPD (Lembar Kerja Peserta Didik) dikarenakan materi pembelajaran tentang sistem indera yang diajarkan kepada peserta didik dapat dilakukan praktikum/percobaan.

Berdasarkan sintaks pembelajaran Discovery Learning tahap pengumpulan data, dapat diketahui bahwa pengumpulan data dengan menggunakan LDPD maupun LKPD kedudukannya sama dimana pada tahap pengumpulan data ini terdapat 2 tahapan yakni pada siklus I, guru menjelaskan prosedur kegiatan diskusi yang terdapat dalam Lembar Diskusi Peserta Didik 
(LDPD) sedangkan pada siklus II, guru mempraktekkan cara kerja mengukur jarak bintik buta dan mengetahui area kepekaan rasa lidah sesuai dengan langkah-langkah yang terdapat pada Lembar Kegiatan Peserta Didik (LKPD) yang diberikan kepada masingmasing kelompok peserta didik.

Dari siklus I hingga siklus II, seluruh kelompok peserta didik mendengarkan penjelasan prosedur kegiatan yang disampaikan guru dengan baik. Hal ini sesuai dengan pernyataan Sani (2017) yang menyatakan bahwa pada tahap persiapan pembelajaran, guru bertindak sebagai pengarah atau pengelola kegiatan dengan cara mengarahkan pengembangan rencana penyelidikan yang hendak dilakukan oleh peserta didik melalui memberikan penjelasan prosedur percobaan agar pembelajaran dengan menggunakan model Discovery Learning dapat berjalan efektif.

Selanjutnya, tahapan kegiatan guru yang kedua adalah guru membimbing kelompok peserta didik untuk mengumpulkan data diskusi maupun percobaan. Pada tahap ini, peserta seluruh kelompok peserta didik harus aktif pada saat mengumpulkan data dari pertanyaan diskusi yang terdapat dalam LDPD maupun data percobaan yang dilakukan. Menurut Roestiyah (2008) tahapan pengumpulan data melatih peserta didik untuk menggunakan metode ilmiah dalam menyelesaikan masalah, sehingga tidak mudah percaya pada sesuatu yang belum pasti kebenarannya. Selain itu juga, pengalaman belajar melalui eksperimen bisa membantu peserta didik mengingat lebih lama, dan memberikan pengalaman langsung sehingga pembelajaran menjadi lebih bermakna (Patrianingsih, 2017).

\section{4) Pengolahan Data}

Pada tahap pengolahan data ini, guru membimbing kelompok peserta didik dalam mengolah data hasil diskusi maupun percobaan. Seluruh kelompok peserta didik dibimbing oleh guru untuk berdiskusi dengan sesama anggota kelompoknya dalam upaya pemecahan masalah maupun memahami sendiri konsep materi yang didapatkan peserta didik setelah melakukan pengunmpulan data, agar pemahaman konsep tersebut dapat diingat oleh peserta didik dalam jangka waktu yang lama. Hal ini sesuai dengan pernyataan Nurgazali (2019) bahwa dalam pengaplikasiannya model Discovery Learning mengembangkan cara belajar peserta didik aktif dengan menemukan sendiri, menyelidiki sendiri, maka hasil yang diperoleh akan tahan lama dalam ingatan serta posisi guru di kelas sebagai pembimbing dan mengarahkan kegiatan pembelajaran sesuai dengan tujuan.

5) Pembuktian

Pada tahap pembuktian, guru membimbing kelompok peserta didik dalam melakukan verifikasi atau pembuktian data melalui membandingkan hasil diskusi maupun percobaan dengan buku/literatur lainnya. Tahap pembuktian ini juga dilakukan dengan cara peserta didik mempresentasikan hasil diskusi bersama dengan anggota kelompoknya dan guru menambahkan atau mengarahkan hasil diskusi peserta didik ke bagian yang lebih benar. Hal ini sesuai dengan pernyataan Widiadnyana (2014) yang menyatakan bahwa pada tahap verifikasi peserta didik melakukan pembuktian, perbaikan, dan pembenaran terhadap hasil yang diperoleh melalui presentasi dan diskusi kelas. Kegiatan ini dapat memunculkan sikap kritis, percaya diri, kemauan mengubah 
pandangan terhadap jawaban karena terungkap bukti-bukti dari informasi yang telah dipelajari. Interaksi dengan lingkungan dapat memperbaiki pemahaman dan memperkaya pengetahuan (Jauhar, 2011).

\section{6) Kesimpulan}

Pada tahap kesimpulan ini, guru membimbing kelompok peserta didik untuk membuat kesimpulan hasil diskusi maupun percobaan tentang sistem koordinasi dengan memperhatikan tujuan dari proses pembelajaran yang dilakukan serta hasil dari diskusi peserta didik. Selain itu, dari tahap kesimpulan ini juga guru dapat melihat tingkat keberhasilan peserta didik dalam proses pembelajaran. Menurut Abidin (2004) pada tahap menarik kesimpulan, peserta didik menarik sebuah kesimpulan yang dapat dijadikan prinsip umum dan berlaku untuk semua kejadian atau masalah yang sama, dengan memperhatikan hasil verifikasi.

Hasil belajar ranah pengetahuan peserta didik secara klasikal pada siklus I yaitu $54,28 \%$ dan mengalami peningkatan di siklus II menjadi $82,85 \%$. Hal ini berarti hasil belajar peserta didik dalam ranah pengetahuan dapat dikatakan tuntas. Hal ini didukung oleh hasil penelitian sebelumnya Novita (2018) bahwa model Discovery Learning dapat meningkatkan hasil belajar peserta didik dengan hasil belajar pada siklus I yaitu $65,71 \%$ meningkat menjadi $82,85 \%$ pada siklus II. Selanjutnya, penelitian oleh Astuti (2018) yang menyimpulkan bahwa penelitian dengan menggunakan model Discovery Learning dapat meningkatkan hasil belajar peserta didik.

Hasil belajar peserta didik ranah keterampilan dilakukan dalam 2 siklus dengan menggunakan LDPD dan LKPD. Dimana setiap siklusnya terdapat 5 indikator pegamatan keterampilan peserta didik dalam penilaian di proses pembelajaran. Hasil belajar peserta didik yang diperoleh mengalami peningkatan dari siklus I dengan rata-rata skor hasil belajar ranah keterampilan peserta didik pada siklus I yaitu 11,94 menjadi 13,28 di siklus II. Hal ini berarti hasil belajar peserta didik dalam ranah keterampilan termasuk kategori penilaian baik atau dapat dikatakan tuntas. Menurut Rosa (2015) menyatakan bahwa guru tidak hanya menjadikan penilaian pada kemampuan ranah kognitif saja sebagai penilaian atau tolak ukur seorang peserta didik, melainkan ketiga ranah penilaian itu semua karena setiap peserta didik memiliki kemampuan yang berbeda-beda pada setiap ranah. Metode pembelajaran yang sebaiknya digunakan adalah dengan praktikum dimana rata-rata kemampuan psikomotorik peserta didik memiliki nilai tertinggi dibandingkan dengan dua ranah lainnya.

Berdasarkan penelitian yang telah dilakukan, ada beberapa kelebihan maupun kekurangan yang dirasakan peneliti selama menerapkan model pembelajaran Discovery Learning. Kelebihan tersebut adalah: 1) Mampu membuat peserta didik lebih aktif di adalam proses pembelajaran. Model Discovery Learning menuntut peserta didik untuk menemukan konsep, sehingga guru hanya berperan sebagai motivator dan fasilitator bukan sebagai sumber informasi; dan 2) Aktivitas peserta didik menemukan konsep membuat konsep lebih mudah dipahami dibanding hanya mendapatkan konsep dari buku. 


\section{PENUTUP}

\section{Simpulan}

Perbaikan pembelajaran dengan penerapan model Discovery Learning dalam proses pembelajasran biologi dengan materi Sistem Koordinasi dapat meningkatkan hasil belajar ranah pengetahuan dan keterampilan peserta didik Kelas XI IPA 2 SMAN 1 Kepahiang.

\section{Saran}

Untuk penelitian selanjutnya diharapkan dapat mengoptimalkan lagi sintaks-sintaks model Discovery Learning dan juga bisa mengatur waktu saat pelaksanaan proses pembelajaran dengan sebaik mungkin supaya diperoleh hasil belajar yang baik.

\section{DAFTAR PUSTAKA}

Abidin, Yunus. 2014. Desain Sistem PembelajaranDalam Konteks Kurikulum. 2013. Bandung: PT Refika Aditama

Amyani, E. S., Irwandi A., \& Sri I. 2018.Penerapan Model Discovery Learning untuk Meningkatkan Aktivitas dan Hasil Belajar Siswa. Diklabio: Jurnal Pendidikan dan Pembelajaran Biologi. 2(1): $\quad$ 15-20. (https://ejournal.unib.ac.id/index.php/ jppb/article/view/5137/2696), diakses tanggal 13 Juli 2019

Ashyuri, A. B., Maridi \& Slamet S. 2017. Pengaruh Penerapan Model Guided Discovery Learning Metode Concept Maps dan Mind Maps terhadap Penguasaan Konsep Biologi Siswa SMA. Proceeding Biology Education Conference. 14 (1): 301-304. (Online). (https://jurnal.uns.ac.id/prosbi/article/ view/17860/14258), diakses tanggal 8 September 2018

Astuti, T. I., Irdam I., \& Yennita. 2018. Penerapan Model Pembelajaran Discovery Learning Untuk Meningkatkan Hasil Belajar Pada Materi Biologi Siswa SMP. Diklabio: Jurnal Pendidikan dan Pembelajaran Biologi. 2 (1): 5-9. (Online). (https://ejournal.unib.ac.id/ index.php/jppb/article/view/5124/269 ), diakses tanggal 13 Juli 2019

Jauhar, M. 2011. Implementasi Paikem dari Behavioristik sampai Konstrukti-vistik. Jakarta: Prestasi Pustaka Publisher

Kemendikbud, 2014. Peraturan Menteri Pendidikan dan Kebudayaan Republik Indonesia Nomor 59 tahun 2014 tentang Kurikulum 2013 Sekolah Menengah Atas/Madrasah Aliyah. Jakarta: Kemendikbud

Mulyatiningsih, Endang. 2013. Metode Penelitian Terapan Bidang Pendidikan. Bandung: Alfabeta

Novita, F., Sri I., \& Dewi J. 2018. Peningkatan Aktivitas Dan Hasil Belajar Melalui Model Discovery Learning Dengan Pendekatan Saintifik. Diklabio: Jurnal Pendidikan dan Pembelajaran Biologi. 2

86-93. (Online).(https://ejournal.unib.ac.id/in dex.php/jppb/article/view/6811/3403) , diakses tanggal 13 Juli 2019.

Nurgazali, Fadhlan. 2019. Model Discovery Learning Dalam Pembelajaran Matematika. Jurnal Pendidikan Matematika. 1: 1-9. (Online). (https://www.researchgate.net/ publication/330411031_Model_Discov ery_Learning_Dalam_Pembelajaran_M 
atematika), diakses tanggal 20 Maret 2019

Patrianingsih, E. A., Nurhayati B., \& Ernawati S. K. 2017. Pengaruh Model Pembelajaran Discovery Learning Terhadap Pemahaman Konsep Biologi Dan Sikap Ilmiah Peserta Didik Sma Negeri 3 Takalar. UNM Journal of Biological Education. 1 (1): 31-46. (Online).

(https://ojs.unm.ac.id/UJBE/article/vie w/5382/3120), diakses tanggal 12 Juli 2019

Putrayasa, I. M., H. S., \& I G. M. 2014. Pengaruh Model Pembelajaran Discovery Learning dan Minat Belajar Terhadap Hasil Belajar Ipa Siswa. Jurnal Mimbar PGSD Universitas Pendidikan Ganesha Jurusan PGSD. 2 (1): 1-11. (Online) .(https://ejournal.undiksha. ac.id/index.php/JJPGSD/article/view/3 087/2561), diakses tanggal 29 Juni 2019

Roestiyah. 2008. Strategi Belajar Mengajar. Jakarta: Rineka Cipta

Rosa, Friska O. 2015. Analisis Kemampuan Siswa Kelas X Pada Ranah Kognitif, Afektif dan Psikomotorik. Jurnal Fisika dan Pendidikan Fisika. 1 (2): 1-5. (Online).

(http://omega.uhamka.ac.id/index.php /omega/article/view/37/43), diakses tanggal 22 Juni 2019

Sani, Ridwan Abdullah dan Sudiran. 2017.

Penelitian Tindakan Kelas

Pengembangan Profesi Guru.

Tangerang: Tsmart

Sardiman, 2007. Interaksi dan Motivasi Belajar. Bandung: Rajawali Pers
Sudijono, A. 2014. Pengantar Statistik Pendidikan. Jakarta: Rajawali Pers.

Suhada, R., Irdam I., \& Kasrina. 2019. Peningkatan Hasil Belajar Siswa Melalui Penerapan Model Pembelajaran Discovery Learning. Diklabio: Jurnal Pendidikan dan Pembelajaran Biologi. 3(1): 32-40. (Online).

(https://ejournal.unib.ac.id/index.php/ jppb/article/view/7816/3956), diakses tanggal 13 Juli 2019

Utomo, Mugi. 2015. Penerapan Metode Disco-very Learning Untuk Meningkatkan Motivasi Belajar Siswa Kelas X Mata Pelajaran Biologi Materi Jamur Di Sma Negeri 3 Simpang Hilir Kabupaten Kayong Utara Tahun Pelajaran 2015/2016. Jurnal Visi IImu Pendidikan. 7 (3): 1809-1820. (Online). (http://jurnal.untan.ac.id/index. php/jvip/article/view/17185), diakses tanggal 29 Juni 2019

Widiadnyana, I W., I W. S., \& I W. S. 2014. Pengaruh Model Discovery Learning Terhadap Pemahaman Konsep IPA dan Sikap Ilmiah Siswa SMP. e-Journal Program Pascasarjana Universitas Pendidikan Ganesha Program Studi IPA. 4: 1-13. (online). (http://119.252.161254/ejournal/in dex.php/jurnal_ipa/article/view/1344/ 1036)diakses tanggal 22 Maret 2019 